\title{
Significance of Emotional Intelligence in Occupational Perspective: A Critical Review
}

\author{
Amita Das* Alvy Riasat Malik \\ Assistant Professor, Department of Human Resource Management, Jatiya Kabi Kazi Nazrul Islam University, \\ Trishal, Mymenshingh, Bangladesh
}

\begin{abstract}
With the beginning of the fifth industrial revolution, Artificial Intelligence has changed the nature of work where human needs to be more creative, innovative, and relationship oriented. For a sustainable working environment, the value of emotional and social competencies has increased day by day while Emotional Intelligence (EI) has captured as a pinnacle in Human Resource Development literature. The study focused on the significance of Emotional Intelligence from an occupational perspective. The findings reveal why an organization should care about the emotional intelligence of its employees. Since an organization can attain a competitive advantage through the people, hence Emotional intelligence could make a difference from an average performer to high-value performer. In this study, the role of Emotional Intelligence has critically analyzed with the evidence of empirical researches published in peer-reviewed journals. The study underlines the essentials of EI in job performance, job satisfaction, Organization citizenship behavior, leadership effectiveness, Team Management, Work-life balance and Employee wellbeing. From the Human Resource Development perspective, organization should emphasize on developing Emotional Intelligence of its employees to make them productive, satisfied and committed for achieving organization's goals and maintaining better working environment.
\end{abstract}

Keywords: Emotional Intelligence, Organizational effectiveness, Human Resource Development

DOI: $10.7176 / \mathrm{EJBM} / 11-18-14$

Publication date: June $30^{\text {th }} 2019$

\section{Introduction:}

As one group of writers has argued: "If the driving force of intelligence in twentieth-century business has been IQ, then ... in the dawning twenty-first century, it will be EQ" (Cooper \& Sawaf, 1997, p. xxvii).

Since the nature of work is changing with the advancement of technology, three types of skills are increasingly important in labor markets: advanced cognitive skills such as complex problem-solving, socio-behavioral skills such as teamwork, and skill combinations that are predictive of adaptabilities such as reasoning and self-efficacy. Building these skills requires strong human capital foundations and lifelong learning (world development Report2019)

Hence, to maximize business excellence through organizational effectiveness, members need to be highly emotionally intelligent which is also known as social intelligence. It helps people to understand their own mentality and develop an empathetic understanding of other peoples' behavior that is helpful for social relationship building and motivate people for goal achievement. Emotionally intelligent employees will consistently excel in leadership, teamwork, partnership, interpersonal relationship, because they have the insight to make a relationship between the staffs, directors, customers, competitors, networking contacts, and so on. Therefore, as social intelligence, emotional intelligence is essential for survival in business and organizational networking.

Daniel Goleman explores an emerging new science of social intelligence with startling implications for our interpersonal world. Its most fundamental discovery:

we are designed for sociability, constantly engaged in a "neural ballet" that connects us brain to brain with those around us. Our reactions to others and theirs to us have a far-reaching biological impact, sending out cascades of hormones that regulate everything from our hearts to our immune systems, making good relationships act like vitamins--and bad relationships like poisons. We can "catch" other people's emotions the way we catch a cold, and the consequences of isolation or relentless social stress can be life-shortening (Goleman, 2006).

Studies showed that Employees' Emotional intelligence ability is positively related to organizations and employees' positive outcomes. Sometimes the effect of EI on an organization can be observed with the help of mediating factors like job satisfaction, work-life balance, organizational learning capacity, job autonomy, organizational citizenship, and counterproductive work, etc. Emotional intelligent help to reduce work anxiety, interpersonal and intrapersonal conflict, make people satisfied with job and life, foster employees' productivity and motivation, enhancing effectiveness and efficiency level. Therefore, as a competency emotional intelligence is applicable to every human interaction in business; having a high average Emotional Quotient (EQ) in the organization will help with customer service, Interpersonal relationship, brainstorming ideas, company presentations, and a myriad of other activities. 


\section{Objective}

The Main objective of the study is to examine the role of Emotional Intelligence to enhance organizational effectiveness through employee performance. Therefore, a number of specific objectives have emanated to support the key objective, they are as follows.

- To identify the nature of Emotional Intelligence

- To examine the importance of Emotional Intelligence on job performance

- To find the key channel of how Emotional Intelligence affect organization performance through employee performance

- $\quad$ To find ways of improving employees' Emotional Intelligence

\section{Methodology}

The study is descriptive and desk-research in nature. Relevant available literature has been rigorously studied. Only secondary data is the base of the study. For this purpose, relevant journals, books, and research papers have been explored. Apart from these, online sources are also used to carry out the study. To make the study more informative and purposive the data has been analyzed and interpreted clearly.

\section{Concept of Emotional Intelligence}

Individuals show a different behavior, depending on their perceptions and skill differences through which they can understand their feelings and the feelings of other persons with empathy and upon their understanding catalyze the behavior to motivate people through social relationship building. This kind of skill is known as emotional intelligence or social intelligence. Gardner (1983) developed the idea that in addition to cognitive intelligence Humans possess multiple intelligences, including interpersonal, intra-personal, physical, visual, special, artistic, environmental and kinesthetics. He claimed that inter- and intra-personal intelligence are as important as IQ. However, Salovey and Mayer (1990) first used the term 'emotional intelligence' as a new form of social intelligence and perhaps the most widely accepted scientific definition of EI is "the ability to monitor one's own and others' emotions, to discriminate among them, and to use the information to guide one's thinking and actions" (Salovey \& Mayer, 1990, p. 189). Emotional intelligence includes self-awareness and impulse control, persistence, zeal and self-motivation, empathy and social deftness and lack of emotional intelligence can sabotage the intellect and ruin careers (Goleman, 2006).

Tony Morrison (2007) explained the basic EI paradigm with four domains, which are visually represented by the following Figure.

Figure 1: The Emotional Intelligence Paradigm

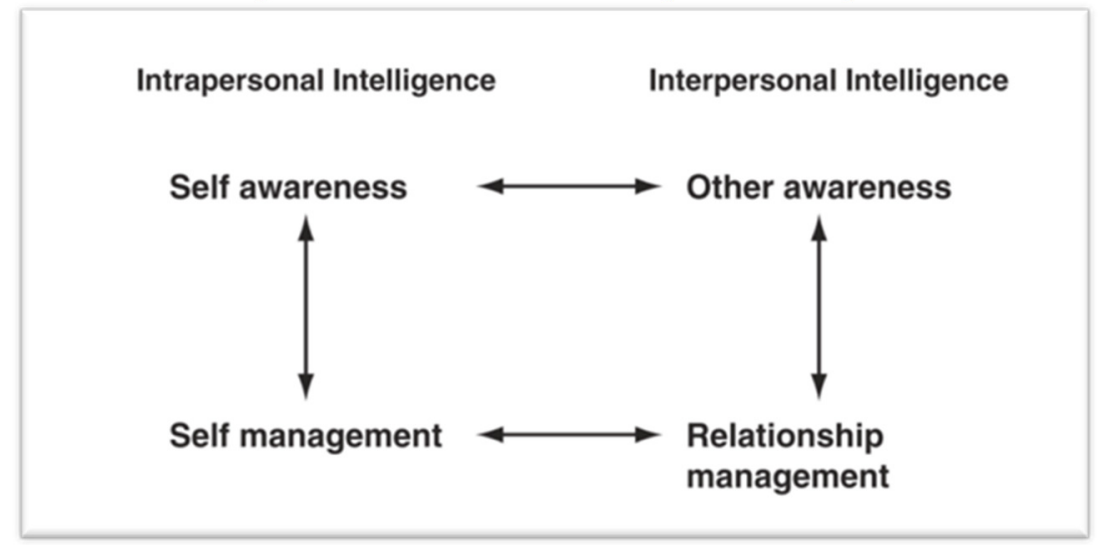

Source: Tony Morrison, British Journal of Social Work (2007) 37, 245-263

There are two intra-personal domains - self-awareness and self-management - and two inter-personal domains - awareness of others/empathy and relationship skills. The arrows indicate the interrelationships that exist between all four domains. The arrows indicate the interrelatedness across the four domains, particularly between self-awareness and empathy for others as a basis for managing self and relationships.

Most EI authors typically distinguish EI approaches into two broad categories: ability models and mixed models (Brackett, Rivers, Shiffman, Lerner, \& Salovey, 2006; Mayer \& Salovey, 1997; Rosete \& Ciarrochi, 2005). Zeidner, Matthews \& Roberts (2004), in their critical review of EI, provided a thorough comparison of the differences in models, dividing the features into two camps - ability-based, and mixed or trait models of EI. He explained, mixed models, are typically used to present EI as a set of competencies that should help individuals be more effective in responding to their environment, whereas ability-based models focus on a "well defined and conceptually related set of cognitive abilities for the processing of emotional information and regulating emotion adaptively". 


\section{Components of emotional intelligence:}

Goleman (1995) developed a performance-based model of EQ to assess employee levels of emotional intelligence, as well as to identify areas of improvement. The model consists of five components, stated below.

a. Self-awareness can be defined as "the ability to recognize and understand your own emotions" (Cherry, 2018B). self-awareness helps to make a SWOT analysis of one's own emotion and develop selfconfidence through an understanding of the negative and positive aspects and effects of person's own emotion so that he/she can regulate his/her feelings for better outcomes.

b. Self-regulation is one step further-to have high EQ, we must not only be able to recognize our own emotions, we need to understand other's emotion with empathy and we must also be able to appropriately express, regulate, and manage our emotion to influence others for best outcomes.

c. Social Skill: Connecting with people in professional settings, managers, leaders, and employees benefit by being able to build interpersonal relationships with subordinates, followers and co-workers and other employees which is an important aspect of emotional intelligence. People with Higher EQ can cultivate Some important social skills include active listening, verbal communication skills, nonverbal communication skills, leadership, and persuasiveness.

d. Motivation: People who are high in EQ are generally achievement-oriented focus on more intrinsic motivation. In other words, people high in EQ prioritize to fulfill their own inner needs and goals and strive to improve or meet a standard of excellence.

e. Empathy can be defined as the ability to understand how other people are feeling and recognize, on an intimate level, how you would feel in their shoes. It does not mean you sympathize, validate, or accept their behavior, just that you can see things from their perspective and "feel" what they feel (Ackerman, 2019).

Goleman argues that individuals that adopt these characteristics give themselves a far greater chance of being successful than individuals that do not. However, individuals are not simply born with these skills and they can be learned.

\section{Emotional Intelligence and Workplace Effectiveness}

EI is claimed to affect a wide array of work behaviors, including employee commitment, teamwork, development of talent, innovation, quality of service, and customer loyalty. In a study of division heads of a global food and beverage company, McClelland (1998) found that the divisions of the leaders with strengths in EI outperformed their yearly revenue targets by a $15 \%$ to $20 \%$ margin. Emotional intelligence is considered an important factor in organizational success through employee performance. The following section has discussed the role of EI in the workplace with the support of previous empirical research in this arena.

\section{i. Emotional Intelligence and Job Performance:}

Employees with higher emotional intelligence have higher job performance (Wong \& Law,2002; Law, Wong, \& Song, 2004; Sy, Tram, \& O'Hara, 2006; Devonish \& Devonish, 2016). The meta-analysis result of Van Rooy and Viswesvaran (2004) reported a .23 operational validity of EI in predicting performance and they found EI as a valuable predictor of performance. Since Employees with high EI could be more proficient at regulating their emotion, they experience more confidence and control over the requirements (task and relationship) of their jobs, while making them more proactive that positively influence work outcomes. Executives higher on EI are more likely to achieve business outcomes and be considered as effective leaders by their subordinates and direct manager ( Palmer, Walls, \& Stough, 2001; Rosete \& Ciarrochi, 2005). Furthermore, in service-oriented business customers are more satisfied with the managers of high EI competencies (Langhorn, 2004). A study, conducted by Lopes, Grewal, Kadis, Gall \& Salovey (2006), assessed the emotional intelligence of analysts and administrative employees with a performance test and assessed work outcomes through peer and supervisor ratings and company data and found that emotional intelligence was related to several indicators of work performance, including: company rank, percent merit increase, and ratings of interpersonal facilitation, and affect and attitudes. Most relationships remained significant when controlling for other predictors, one at a time.

Another study conducted by Cavallo (2006) where more than fourteen hundred employees took part in a one hundred and eighty-three question multi-rater survey that measured a variety of competencies associated with leadership performance including those commonly referred to as Emotional Intelligence and the results showed that the highest performing managers have significantly more "emotional competence" than other managers. There was strong inter-rater agreement among Supervisors, Peers, and Subordinates that the competencies of SelfConfidence, Achievement Orientation, Initiative, Leadership, Influence and Change Catalyst differentiate superior performers. High performing managers at the Johnson \& Johnson Consumer and Personal Care Group were seen to possess significantly higher levels of Self-Awareness, Self-Management capability, Social Skills, and Organizational Savvy, all considered part of the Emotional Intelligence domain. This study supports the position that emotional competence differentiates successful leaders (Cavallo, 2006; Ramo, Saris, \& Boyatzis, 2009). Laban P. Ayiro (2009) found a strong positive correlation between total EI score and performance ratings $(\mathrm{r}=.37$, 
$\mathrm{p}<.001$ ) and by conducting a study on 100 principles of selected schools in Kenya he found that $13.7 \%$ of the variation in performance ratings can be predicted by the principal's total EI score.

\section{ii. Emotional Intelligence and Job Satisfaction:}

Employees who have affection or emotional regulation processes and strategies (EI) tend to have higher levels of job satisfaction (Bar-On 1997; Greenidge, Devonish, \& Alleyne, 2014; Çekmecelioğlu, Günsel, \& Ulutaş, 2012; Tagoe, \& Quarshie, 2016; Devonish \& Devonish, 2016). Employees with higher emotional intelligence (EI) have higher job satisfaction, higher organizational commitment, and lower turnover intentions. EI improves job satisfaction by helping employees reduce negative feelings, by increasing positive feelings, and/or by improving job performance and employees show strong job satisfaction when a job requires high levels of emotional labour (Miao, Humphrey, \& Qian, 2017). Abraham, 2000, showed EI predicts a large amount of variance in job satisfaction and EI exerts a more powerful influence in conjunction with job autonomy. Employees with higher EI feel more satisfied When they can independently make decisions and have control over their own job. Furthermore, workers with high EI will have a tendency to choose working contexts which facilitate and foster organizational learning capabilities (OLC), whereby employees perceive higher levels of job satisfaction. The role of OLC can be explained by the fact that emotionally intelligent individuals tend to work in conditions that propitiate their emotional and social abilities (teamwork, risk-taking, dialogue, participation, etc.), and consequently, they are likely to have higher levels of job satisfaction. OLC might thus be considered as a stimulating working context, where emotionally intelligent people can develop their competencies and achieve satisfaction (Chiva \& Alegre, 2008).

\section{iii. Organizational Citizenship behavior (OCB) and Counterproductive work behavior (CWB):}

HRM practices, such as recruitment and selection and training and development, should be more emotion-oriented or focused. To select employees with effective emotional regulation tendencies, EI and theoretically relevant personality traits in employee selection systems can reduce negative emotion as well as CWB and enhance OCB (Greenidge \& Coyne, 2014).

Sackett \& DeVore (2001) defined OCBs as, “...positive behaviors that contribute to organizational effectiveness, but that do not reflect core job tasks." and CWBs as, "... any intentional behavior on the part of an organizational member viewed by the organization as contrary to its legitimate interests."

Hence, emotional intelligence becomes a stronger predictor of task performance and organization oriented organizational citizenship behavior (OCBO). Employees with low cognitive intelligence perform tasks effectively and engage in OCBO frequently if they are emotionally intelligent (Cote \& Miners,2006).

employees who have affection or emotional regulation processes and strategies tend to have higher levels of job satisfaction and engage in higher levels of contextual performance and lower levels of counterproductive behavior (Greenidge, Devonish, \& Alleyne, 2014).

Recently researchers found that EI is positively and significantly related to both OCB-I (Individual oriented OCB) and OCB-O (Organization oriented OCB) equally such that high EI employees demonstrated higher levels of these two types of citizenship behavior (Devonish and Greenidge, 2010; Greenidge et al., 2014; Alfonso et al., 2016).

\section{iv. Leadership effectiveness:}

Effective leaders have specific attributes, skills and specific styles through which they create a situation that is best for the organization. Leadership effectiveness depends on subordinates' performance, satisfaction, loyalty and overall organizational performance (Madanchian, Hussein, Noordin, \& Taherdoost, 2017).

An individual's EI may indeed be a key determinant of effective leadership. Employee perceptions of supervisor effectiveness are strongly related to the EI of the supervisor (Kerr, Garvin, Heaton, \& Boyle, 2006; Rosete \& Ciarrochi, 2005). Moreover emotional intelligence correlated with several components of transformational leadership, suggesting that it may be an important component of effective leadership, that may account for how effective leaders monitor and respond to subordinates and make them feel at work (Palmer et al., 2001)

Research also found a positive relationship between EI and transformational leaders- who are able to motivate and inspire others, to foster positive attitudes at work and to create a sense of contribution and importance with and among employees whereas a negative relationship was observed between EI and laissez-faire leadershipwhich is characterized by a disregard for the responsibilities of managing followers, failure to discriminate amongst feelings, and to regulate mood. (Downey, Papageorgiou, \& Stough, 2006).

By addressing 24 project managers and their associated projects in six organizations from varied industries, Leban \& Carols (2004) found that a project manager's transformational leadership style has a positive impact on actual project performance, and emotional intelligence ability contributes to a project manager's transformational leadership style and subsequent actual project performance (Leban \& Zulauf, 2004).

Sivanathan \& Cynthia Fekken found that flowers' evaluation of leaders' transformational behaviors was positively related to leaders' self-reports of emotional intelligence and resident ratings on leadership effectiveness but Interestingly, having high emotional intelligence was not related to supervisor's ratings of effectiveness. The 
findings reveal that followers and supervisor measure of leadership effectiveness varies depending on role behavior while followers focus on social relationship and supervisors associated greater job effectiveness with higher moral reasoning.

On the contrary, Weinberger, (2009) found there is no relationship between EI and leadership style and outcome variables of leadership, namely leadership effectiveness, satisfaction with the leader, and extra effort. Based on the ability based EI measurement which has little utility in organizational perspective, the study conducted a survey on a single manufacturing firm. Therefore, the findings should not be generalized and more research is required to justify the EI and leadership effectiveness.

\section{v. Successful team management:}

Research finds that supervisors' level of Emotional intelligence can have an impact on subordinates' job satisfaction. Employees feel more attached with the group as well as an organization when they are supported by Emotionally Intelligent supervisors and that perception helps to fulfill task attainment with satisfaction while reducing turnover intention (Whiteoak \& Manning, 2012). On the other hand, supervisors' emotional exhaustion acts as an important risk factor for subordinates' perceptions of abusive supervision (Lam, Walter, \& Huang, 2017). Therefore, employees' commitment to group and organization tends to be lower when the supervisor possesses low or poor emotional Intelligence competency.

\section{vi.Better Work-Life Balance:}

Employees with higher EI can successfully manage work-life balance by reducing the work-family conflict(Biggart, Corr, O’Brien, \& Cooper, 2010; Gao, Shi, Niu, \& Wang, 2013; Kanti \& Seshadri,2019). Employees with stable emotion can control the stresses originated from work and family. Thus, employees who are high in EI will be able to actively and effectively deal with demands and pressures from family or work context. Contrary, those who are low in EI are likely to be weak in managing their emotions and relations; which may lead to the development of frustration and conflict (Suliman \& Al-Shaikh, 2007).

\section{vii. Employees Wellbeing:}

Employee well-being refers to the quality of employees' functioning and experiences in organizations (Grant, Christianson, and Price, (2007) Employees with higher emotional intelligence can build a good interpersonal relationship with peers, subordinates, and supervisors that could help to reduce and manage psychological stress. Evidence support for the positive association between emotional intelligence and psychological wellbeing components - self-esteem, life satisfaction, and self-acceptance (Carmeli, Yitzhak-Halevy, \& Weisberg, 2009).Improving emotional intelligent levels among employees can add value to employees who may be constantly exposed to significant mental health risks at work (Devonish,2016). Moreover, employees with higher EI can effectively manage intra-individual conflict, namely: Frustration, goal conflict and role conflict (workfamily conflict)(Suliman \& Al-Shaikh, 2007) which ultimately fosters employee wellbeing. Therefore, researches in EI suggest that emotionally intelligent employees tend to have better mental or psychological health due to their enhanced ability to manage their emotions and affective states which, in turn, can influence their willingness to engage in positive work behaviours (Higgsa, \& Dulewiczb, 2014). Greenidge and Coyne, 2014; Greenidge et al., 2014; Mayer and Salovey, 1997; Slaski and Cartwright, 2003).

A most recent study found that EI is not significantly related to either satisfaction or psychological health outcomes but EI, can help to mitigate the negative effects of stressors on the experience of strain. Therefore, high EI employees may develop an understanding of the environment that facilitates more positive and fewer negative emotional responses that pave the way for more adaptive coping (Newton, Teo, Pick, Ho, \& Thomas, 2016).

\section{Can Emotional Intelligence be developed? How?}

Emotional Intelligence captured the mind of Human Resource Development practitioners because of the fact that "emotional intelligence develops over a person's life span and can be enhanced through training" (Ashkanasy \& Daus, 2002, p. 81; Kozlowski, Hutchinson, Hurley \& Browne, 2018). Degrees of EI varies depending on the education, age, and experience of employees. Highly educated, experienced and older employees report higher EI competency (Suliman \& Al-Shaikh, 2007).

By conducting a meta-analysis ( pre-post and control-treatment experiment) Mattingly, \& Kraiger (2019) found the effect of training on EI is both moderate and positive and the effect is higher in the peer-reviewed published paper than in dissertations and was robust across participant gender and type of EI measure, thus confirming that scores on EI measures can be increased via training.

Social and emotional competency can be developed by social interaction in the workplace and other life spheres like family and education where the social environment plays a vital role (Wheeler, 2008).In education life sphere emotional, social and cognitive intelligence competencies can be developed in adults through a graduate management program like MBA and these improvements can sustain out as far as seven years. But this degree of value added can be eroded by a tumultuous organizational climate, continuous improvement and renewal can uphold the competency level(Boyatzis \& Saatcioglu, 2008). 


\section{Conclusion:}

From the above review analysis, it is clear that EI competency is essential for smooth organizational performance. Employees with higher EI score can manage their emotion and influence other employees' emotion by observing the situation with empathy. Compare to sympathy, Feelings of Empathy is important to solve a problem in a positive way. EI helps to strengthen the interpersonal relationship among colleagues, leader-followers, bosssubordinates which is essential for the sound organizational environment to foster organizational effectiveness and employees' wellbeing. Findings of the literature search have confirmed the positive effects of EI (Emotional Intelligence) on employees and organizations. Employees with higher emotional intelligence have a higher level of job satisfaction that helps to enhance organizational outcomes. Higher EI induces employees to show organizational citizenship behavior, besides this EI helps to manage and reduce the stress level that prevents them to engage in counterproductive work behavior to the organization. Leaders and /or managers with higher EI can manage their team effectively with followers' satisfaction and commitment compare to leaders with lower EI. Overall Employees with higher EI positively related to employee wellbeing and organizational outcomes. Therefore, Emotional Intelligence competency should get priority in recruitment and selection, training and development and performance evaluation. Since the research area is at the beginning stage, further research is needed to empirically test the effect of EI in the occupational environment. Future research could focus on the effect of EI in organizational conflict resolution and building interpersonal relationship.

\section{References:}

Ashkanasy, N. M., \& Daus, C. S. (2002). Emotion in the workplace: The new challenge for managers. Academy of Management Executive, 16, 76-86.

Ackerman, C. (2019) What is Emotional Intelligence? +18 Ways to Improve It. https://positivepsychologyprogram.com/emotional-intelligence-eq

Abraham, R. (2000). The Role of Job Control as a moderator of Emotional Dissonance and Emotional Intelligence -Outcome Relationships. The Journal of Psychology.134(2), 169-184

Alfonso, L., Zenasni, F., Hodzic, S. and Ripoll, P. (2016), "Understanding the mediating role of quality of work life on the relationship between emotional intelligence and organizational citizenship behaviors", Psychological Reports, Vol. 118 No. 1, pp. 107-127.

Ayiro, L. P. (2009). An analysis of emotional intelligence and the performance of principals in selected schools in Kenya. Advances in Developing Human Resources, 11(6), 719-746. https://doi.org/10.1177/1523422309360958

Bar-On, R. (1995). EQ-I: The emotional quotient inventory manual. A test of emotional intelligence. New York, NY: Multi-Health Systems

Bar-On, R. (1997). Bar-On Emotional Quotient Inventory: Technical manual. Toronto, Ontario, Canada: MultiHealth Systems

Biggart, L., Corr, P., O’Brien, M., \& Cooper, N. (2010). Trait emotional intelligence and work-family conflict in fathers. Personality and Individual Differences, 48(8), 911-916. https://doi.org/10.1016/j.paid.2010.02.020

Boyatzis, R. E., \& Saatcioglu, A. (2008). A 20-year view of trying to develop emotional, social and cognitive intelligence competencies in graduate management education. Journal of Management Development, 27(1), 92-108. https://doi.org/10.1108/02621710810840785

Brackett, M. A., Rivers, E. S., Shiffman, S., Lerner, N., \& Salovey, P. (2006). Relating emotional abilities to social functioning: A comparison of self-report and performance measures of emotional intelligence. Journal of Personality and Social Psychology, 91, 780-795

Carmeli, A., Yitzhak-Halevy, M., \& Weisberg, J. (2009). The relationship between emotional intelligence and psychological wellbeing. Journal of Managerial Psychology, 24(1), 66-78. https://doi.org/10.1108/02683940910922546

Cherry, K. (2018B). Five Components of Emotional Intelligence. Very Well Mind. Retrieved from https://www.verywellmind.com/components-of-emotional-intelligence-2795438

Côté, S., \& Miners, C. T. H. (2006). Emotional Intelligence, Cognitive Intelligence, and Job Performance. Administrative Science Quarterly, 51(1), 1-28. https://doi.org/10.2189/asqu.51.1.1

Cavallo, K. \& Brienza, D.(2006).Emotional Competence and Leadership Excellence at Johnson \& Johnson: The Emotional Intelligence and Leadership Study. European Journal of Psychology. (2), 1.

Çekmecelioğlu, H. G., Günsel, A., \& Ulutaş, T. (2012). Effects of Emotional Intelligence on Job Satisfaction: An Empirical Study on Call Center Employees. Procedia - Social and Behavioral Sciences, 58, 363-369. https://doi.org/10.1016/j.sbspro.2012.09.1012

Chiva, R., \& Alegre, J. (2008). Emotional intelligence and job satisfaction: The role of organizational learning capability. Personnel Review, 37(6), 680-701. https://doi.org/10.1108/00483480810906900

Cooper, R.K., \& Sawaf, A. (1997). Executive EQ: Emotional intelligence in leaders and organizations. New York: Grosset/Putnam. 
Downey, L. A., Papageorgiou, V., \& Stough, C. (2006). Examining the relationship between leadership, emotional intelligence, and intuition in senior female managers. Leadership and Organization Development Journal, 27(4), 250-264. https://doi.org/10.1108/01437730610666019

Devonish, D. \& Greenidge, D.(2010). The Effect of Organizational Justice on Contextual Performance, Counterproductive Work Behaviors, and Task Performance: Investigating the moderating role of abilitybased emotional intelligence. International Journal of Selection and Assessment. 18 (1 ), 75-86

Devonish, D. (2016) "Emotional intelligence and job performance: the role of psychological well- being", International Journal of Workplace Health Management, Vol. 9 Issue: 4, pp.428-442, https://doi.org/10.1108/IJWHM-04-2016-0031

Fambrough, M. J., \& Kaye Hart, R. (2008). Emotions in Leadership Development: A Critique of Emotional Intelligence. Advances in Developing Human Resources, 10(5), 740-758. https://doi.org/10.1177/1523422308323542

Goleman, D. (1995). Emotional intelligence. New York, NY, England: Bantam Books, Inc.

Goleman, D. (2006). Social intelligence: The new science of human relationships. New York, NY, US: Bantam Books.

Gardner, H. (1983) Frames of Mind: The Theory of Multiple Intelligences, New York, Basic Books.

Gao, Y., Shi, J., Niu, Q., \& Wang, L. (2013). Work-family conflict and job satisfaction: Emotional intelligence as a moderator. Stress and Health, 29(3), 222-228. https://doi.org/10.1002/smi.2451

Grant, A.M., Christianson, M.K. and Price, R.H. (2007), "Happiness, health, or relationships? Managerial practices and employee well-being tradeoffs", Academy of Management Perspectives, Vol. 21 No. 3, pp. 51-63.

Hair,

Greenidge, D., \& Coyne, I. (2014). Job stressors and voluntary work behaviours: mediating effect of emotion and moderating roles of personality and emotional intelligence, Human Resource Management Journal. 24(4), 479-495. https://doi.org/10.1111/1748-8583.12044

Greenidge, D., Devonish, D., \& Alleyne, P. (2014). The Relationship Between Ability-Based Emotional Intelligence and Contextual Performance and Counterproductive Work Behaviors: A Test of the Mediating Effects of Job Satisfaction. Human Performance, 27(3), 225-242. https://doi.org/10.1080/08959285.2014.913591

Higgsa, M. \& Dulewiczb, V. (2014). Antecedents of well-being: a study to examine the extent to which personality and emotional intelligence contribute to well-being. The International Journal of Human Resource Management, 25, (5), 718-735, http://dx.doi.org/10.1080/09585192.2013.815253

Joseph, D.L., and Newman, D.A. (2010), "Emotional intelligence: an integrative meta-analysis and cascading model", Journal of Applied Psychology, Vol. 95 No. 1, pp. 54-78

Kerr, R., Garvin, J., Heaton, N., \& Boyle, E. (2006). Emotional intelligence and leadership effectiveness. Leadership and Organization Development Journal, 27(4), 265-279. https://doi.org/10.1108/01437730610666028

Kanti, T. Seshadri V. The Impact of Emotional Intelligence in Managing Work-Life Balance in the IT Industry. International Journal of Research and Analytical Reviews (IJRAR)Volume 6, Issue 1

Kozlowski, D., Hutchinson, M., Hurley, J., \& Browne, G. (2018). Increasing nurses' emotional intelligence with a brief intervention. Applied Nursing Research, 41(April), 59-61. https://doi.org/10.1016/j.apnr.2018.04.001

Lam, C. K., Walter, F., \& Huang, X. (2017). Supervisors' emotional exhaustion and abusive supervision: The moderating roles of perceived subordinate performance and supervisor self-monitoring. Journal of Organizational Behavior, 38(8), 1151-1166. https://doi.org/10.1002/job.2193

Langhorn, S. (2004). How emotional intelligence can improve management performance. International Journal of Contemporary Hospitality Management, 16(4), 220-230. https://doi.org/10.1108/09596110410537379

Law, K. S., Wong, C., \& Song, L. J. (2004). The construct and criterion validity of emotional intelligence and its potential utility for management studies. Journal of Applied Psychology, 89, 483-496

Leban, W., \& Zulauf, C. (2004). Linking emotional intelligence abilities and transformational leadership styles. Leadership \& Organization Development Journal, $25(7), \quad 554-564$. https://doi.org/10.1108/01437730410561440

Lopes, P. N., Grewal, D., Kadis, J., Gall, M., \& Salovey, P. (2006). Evidence that emotional intelligence is related to job performance and affect and attitudes at work. Psichothema. 18, 132-138.

Madanchian, M., Hussein, N., Noordin, F., \& Taherdoost, H. (2017). Leadership Effectiveness Measurement and Its Effect on Organization Outcomes. Procedia Engineering, 181, 1043-1048. https://doi.org/10.1016/j.proeng.2017.02.505

McClelland, C.D. (1998). IDENTIFYING COMPETENCIES WITH BEHAVIORAL-EVENT INTERVIEWS. PSYCHOLOGICAL SCIENCE. VOL. 9, NO. 5, 331-339

Mayer, J.D., \& Salovey, P. (1997). What is emotional intelligence? In P. Salovey \& D.J. Sluyter (Eds.), Emotional development and emotional intelligence: Educational implications (pp. 3-31). New York: Basic Books. 
Mattingly, V. Kraiger, K. (2019). Can emotional intelligence be trained? A meta-analytical investigation. Human Resource Management Review, 29 140-155

Kozlowski, D., Hutchinson, M., Hurley, J., \& Browne, G. (2018). Increasing nurses' emotional intelligence with a brief intervention. Applied Nursing Research, 41(April), 59-61. https://doi.org/10.1016/j.apnr.2018.04.001

Miao, C., Humphrey, R. H., \& Qian, S. (2017). A meta-analysis of emotional intelligence and work attitudes. Journal of Occupational and Organizational Psychology, 90(2), 177-202. https://doi.org/10.1111/joop.12167

Morrison, T. (2007). Emotional intelligence, emotion and social work: Context, characteristics, complications, and contribution. British Journal of Social Work, 37(2), 245-263. https://doi.org/10.1093/bjsw/bcl016

Newton, C., Teo, S. T. T., Pick, D., Ho, M., \& Thomas, D. (2016). Emotional intelligence as a buffer of occupational stress. Personnel Review, 45(5), 1010-1028. https://doi.org/10.1108/PR-11-2014-0271

Palmer, B., Walls, M., Burgess, Z., Stough, C., (2001). Emotional intelligence and effective leadership. Leadership \& Organization Development Journal. Vol. 22 Issue: 1, pp.5-10, https://doi.org/10.1108/01437730110380174

Rosete, D., \& Ciarrochi, J. (2005). Emotional intelligence and its relationship to workplace performance outcomes of leadership effectiveness. Leadership and Organization Development Journal, 26(5), 388-399. https://doi.org/10.1108/01437730510607871

Ramo, L. G., Saris, W. E., \& Boyatzis, R. E. (2009). The impact of social and emotional competencies on effectiveness of Spanish executives. Journal of Management Development, 28(9), 771-793. https://doi.org/10.1108/02621710910987656

Sackett, P. R., \& DeVore, C. J. (2001). Counterproductive behaviors at work. In N. Anderson, D. S. Ones, H. K. Sinangil, \& C. Viswesvaran (Eds.), Handbook ofindustrial, work, and organizational psychology, Vol. 1 (pp. 145-164). London: Sage.

Salovey, P., \& Mayer, J.D. (1990). Emotional intelligence. Imagination, Cognition and Personality, 9, $185-211$.

Sivanathan, N. \& Fekken, C.G. (2002) "Emotional intelligence, moral reasoning and transformational leadership", Leadership \& Organization Development Journal, Vol. 23 Issue: 4, pp.198-204, https://doi.org/10.1108/01437730210429061

Slaski, A.M. and Cartwright, S. (2003), "Emotional intelligence training and its implications for stress, health and performance", Stress and Health, in press.

Sosik, J. J., \& Megerian, L. E. (1999). Understanding leader emotional intelligence and performance: The role of self-other agreement on transformation leadership perceptions. Group and Organization Management, 24, 367-390

Suliman, A. M., \& Al-Shaikh, F. N. (2007). Emotional intelligence at work: Links to conflict and innovation. Employee Relations, 29(2), 208-220. https://doi.org/10.1108/01425450710720020

Sy, T., Tram, S., \& O'Hara, L. A. (2006). Relation of employee and manager emotional intelligence to job satisfaction and performance. Journal of Vocational Behavior, 68(3), 461-473. https://doi.org/10.1016/j.jvb.2005.10.003

Tagoe, T., \& Quarshie, E. N. (2016). The relationship between emotional intelligence and job satisfaction among nurses in Accra. Nursing, 4(2), 84-89. doi:10.1002/nop2.70

Van Rooy, D. L., \& Viswesvaran, C. (2004). Emotional intelligence: A meta-analytic investigation of predictive validity and nomological net. Journal of Vocational Behavior, 65(1), 71-95. https://doi.org/10.1016/S00018791(03)00076-9

Weinberger, L. A. (2009). Emotional intelligence, leadership style, and perceived leadership effectiveness. Advances in Developing Human Resources, 11(6), 747-772. https://doi.org/10.1177/1523422309360811

Wheeler, J. V. (2008). The impact of social environments on emotional, social, and cognitive competency development. Journal of Management Development, 27(1), 129-145. https://doi.org/10.1108/02621710810840802

Wong, C., \& Law, K. S. (2002). The effect of leader and follower emotional intelligence on performance and attitude: An exploratory study. Leadership Quarterly, 23, 243-274.

Whiteoak, J. W., \& Manning, R. L. (2012). Emotional intelligence and its implications on individual and group performance: A study investigating employee perceptions in the United Arab Emirates. International Journal of Human Resource Management, 23(8), 1660-1687. https://doi.org/10.1080/09585192.2011.606121

world development Report-2019.The Changing Nature of Work.

Zeidner,M., Matthews,G., Roberts,D.R.(2004) Emotional Intelligence in the Workplace: A Critical Review. APPLIED PSYCHOLOGY: AN INTERNATIONAL REVIEW, 2004, 53 (3), 371-399 